\title{
Conservation Process of Two Mural Paintings in El Shinawy Palace
}

\author{
Kholod K Salama ${ }^{1 *}$, Mona F Ali² and Abubakr M Moussa ${ }^{2}$ \\ ${ }^{1}$ National Museum of Egyptian Civilization, Egypt
}

${ }^{2}$ Conservation Department, Faculty of Archaeology, Cairo University, Egypt

Submission: July 28, 2018; Published: August 20, 2019

*Corresponding author: Kholod K Salama, National Museum of Egyptian Civilization, Cairo, Egypt

Abstract

In the present study, an investigation has been undertaken in to El Sinawy palace back to the 20th century and built by Italian architect. It is initially located in east delta-Egypt. The investigation used to focus to the deterioration factors facing the palace which will be a museum after finishing the conservation process. The investigation revealed that the most vital deterioration factor facing the mural paintings in El Shinawy palace is the high artificial light and the groundwater which appeared in the flaking of painting layers. The effect of all deterioration factors can be prevented by using simple ways from the preventive conservation.

Keywords: El Shinawy palace; Mural paintings; XRD; Portable Microscope

\section{Introduction}

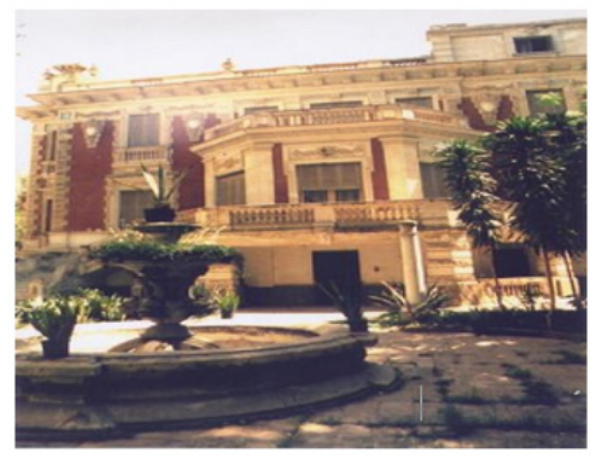

Figure 1: The sinawy palace façade.
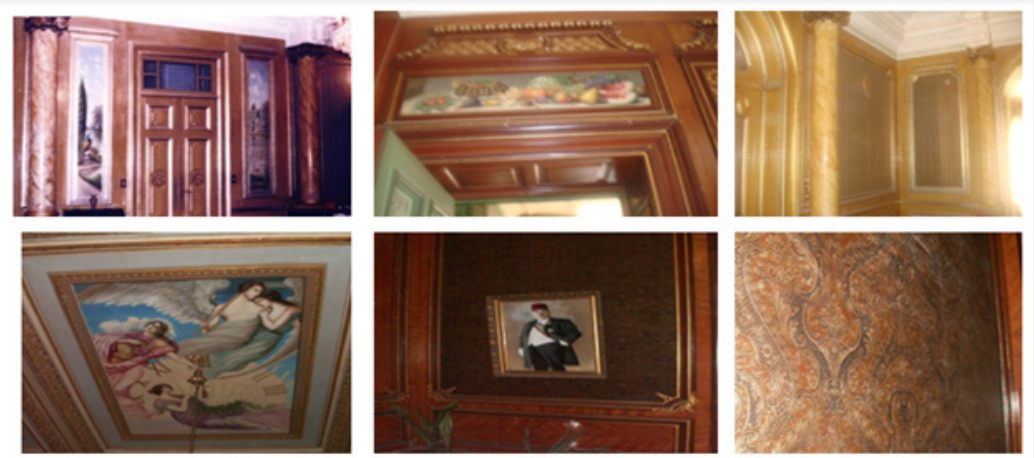

Figure 2: The kinds of accurate fine arts in the shinawy palace, mural paintings, panel paintings, gypsum works, oil paintings applied on the ceil, oil painting picture for the owner and the wallpaper. 


\section{Global Journal of Archaeology \& Anthropology}

The presence of historical palaces is considered the most important monuments which reflect the period circumstances build in. El Shinawy palace (Figure 1) was built for Mohamed Mohamed Bek El Shinawy (a rich merchant-parliament membersenator (the owner of the palace) in the 20th century or to year 1928 the whole space of the palace is $4164 \mathrm{~m} 2$. That palace is full of all kinds of accurate fine arts (Figure 2). The palace has got an award signed by Mussolini-Italian governor- as the prettiest palace built out of Italy by an Italian architect. It is consisted of three floors, that palace is famous because of its decoration as the mural paintings on ceilings and on walls. Many parts of the mural paintings in El Shinawy palace were perfectly preserved while in others, there were flaking paints. In some area the painting layer was entirely lost, but the plaster survived in good condition. The obtained results will be used to apply a scientific plan for restoration and preservation.
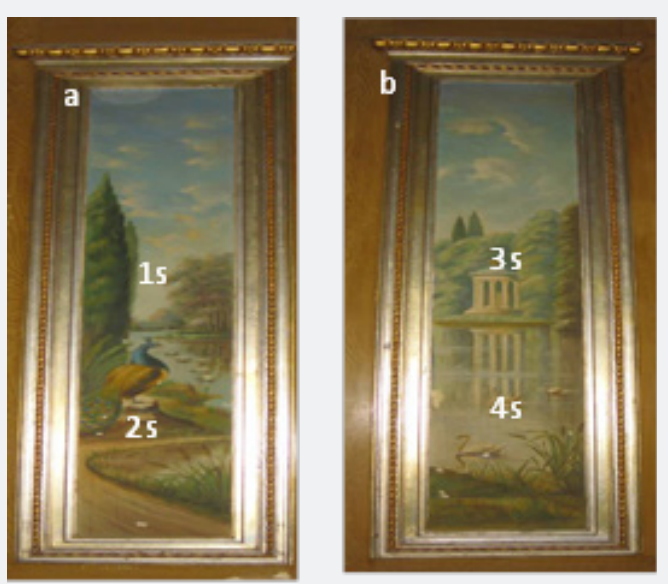

Figure 3: a,b: The two mural paintings in el shinawy palace and samples locations.

Under taken Mural paintings in El Shinawy palace were Rococo style as the colours were light and there is an obvious movement in the birds or in the planets (Figure 3), Those mural paintings exist in food chamber in second floor in El Shinawy palace in El Mansoura city they are rococo style as the colours are light and there is an obvious movement of birds and in the growing of planets their dimensions about $2.27 \mathrm{M} \mathrm{X} 53 \mathrm{~cm}$ with frame it's width $11 \mathrm{~cm}$. The current mural paintings in El shinawy palace were exposed to many deterioration factors amongst; the geometrical factors, the environmental factors, the biological factors, the dynamic deterioration factors which includes the earthquakes and vibrations caused by transportation, in addition to the human made factors. The most common damage is found in the paint layer as a result of moisture; dust is covering those murals because of the long-time opened doors and windows.

The analysis of this painting was carried out in the occasion of the restoration treatment. From the visual inspection the condition of the painting is almost stable, failure in paint layers is the most apparent deterioration phenomenon (Figure 4). Therefore, the pictorial layer suffered from severe loss and color change around the lost areas, grassy spots
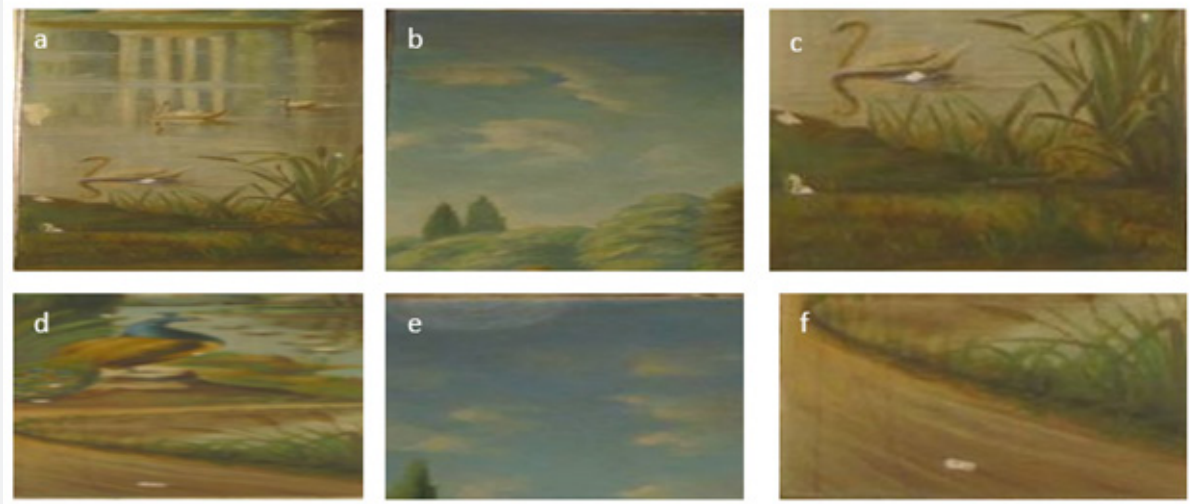

Figure 4: a,b,c: The condition assessment of the first mural painting; $d, e, f:$ The condition assessment of the second mural

a. losing of painting layer.

b. yellowness in.

c. grassy varnish spots.

d. grassy varnish spots.

e. Blisters.

f. vital cracks 


\section{Materials and Method}

\section{Sampling}

Mural paintings of El shinawy palace were studied in order to determine their composition. Mortars, plasters and pigment materials have been sampled for laboratory analyses. All the analyzed and investigated samples were carefully collected from areas without aesthetic value or from severely damaged parts.

Portable Optical Microscope (P.O.M): The paintings were examined with portable optical microscope to identify the color mixture and the micro cracks.

X-Ray Diffraction (XRD): The X-ray diffraction patterns of the paintings were obtained using a diffract meter, operated at
$40 \mathrm{kV}$ and $25 \mathrm{~mA}$, using $\mathrm{Cu}$ Ka radiation and a receiving slit of $0.2 \mathrm{~mm}$. The measurements were made at room temperature. Preparation of each sample consisted of grinding it in the dry form, by using a mortar and pestle to obtain a fine powder [1].

\section{Results and Discussion}

\section{Portable Optical Microscope (P.O.M)}

After examining the paintings the green color composed mainly of fine to medium- grained of grafit, embedded in very fine grained ground mass admixed with considerable homogenous of ground layer, red color mixed with a percentage of fine blue color, the blue color mixed with yellow color and the ground layer contain salts (Figure 5).
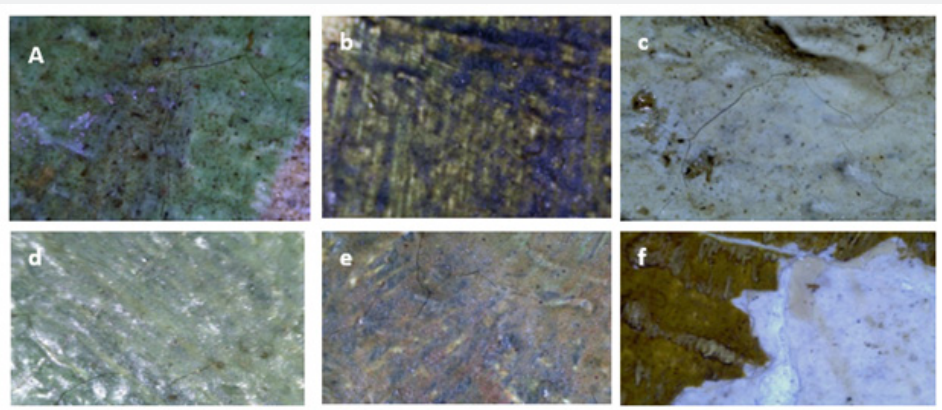

Figure 5: Portable optical microscopic shows structure of paintings.

a. The green color is mixed with grafit and there is a crack on the paint layer.

b. Blue color mixed with a percentage of fine yellow color.

c. Yellow color mixed with grafit and there is a crack on the paint layer.

d. Green and yellow color appeared mixed together.

e. The blue color mixed with red and yellow colors.

f. The ground layer contains salts.

\section{XRD Analyses}

XRD Analysis Results Revealed the Following:

a. Existence of gypsum in the four samples in different percentage assured that the ground layer of mural paintings was made of gypsum and zincate which used for whiteness.
So, the ground layer is consisted of zincate mixed with gypsum in percentage 2:1.

b. The colors which were used in the painting were so familiar in that period

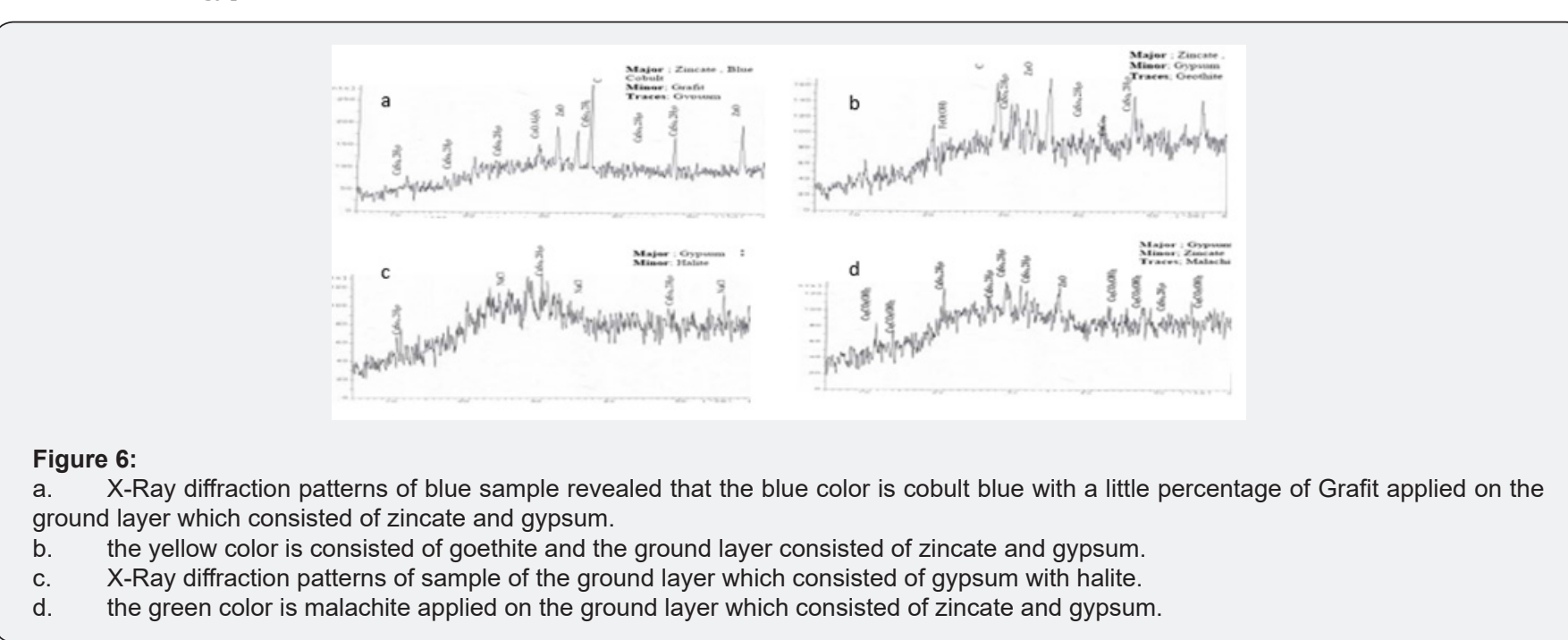


Table 1: The results of X-ray Fluorescence analysis of four samples from paintings of El Shinawy palace the results are confirming the results of $\mathrm{X}$-Ray diffraction analysis.

\begin{tabular}{|c|c|c|c|c|}
\hline Compounds \% & 1s & $2 s$ & $3 s$ & $4 s$ \\
\hline Gypsum $\mathrm{CaSO}_{4} \cdot 2 \mathrm{H}_{2} \mathrm{O}$ & $8 \%$ & $14.60 \%$ & $55.50 \%$ & $46.40 \%$ \\
\hline Zincate $\mathrm{ZnO}$ & $54 \%$ & $45.70 \%$ & ---- & $26 \%$ \\
\hline Grafit C & 24.5 & $32.90 \%$ & ---- & -- \\
\hline Malachite $\mathrm{Cu}_{2} \mathrm{CO}_{3}(\mathrm{OH})_{2}$ & $-\cdots$ & ---- & ----- & $27 \%$ \\
\hline Halit Nacl & ------ & ----- & $44.50 \%$ & ----- \\
\hline Goethite $\mathrm{Fe}_{2} \mathrm{O}_{3}$ & $-\cdots$ & $6.50 \%$ & $-\cdots$ & $-\cdots$ \\
\hline Cobult blue $\mathrm{CoO} \cdot \mathrm{Al}_{2} \mathrm{O}_{3}$ & $13 \%$ & ---- & ---- & ---- \\
\hline
\end{tabular}

c. The yellow color is Goethite, the green color is the malachite, the blue color is cobult, (Figure 6) (Table 1).

d. Halite constitutes of the ground layer in $40 \%$ that result assured the occurrence of deterioration which can cause detachment in the future [2], which caused the detachment of painting layers or blisters Ashurst [3] by XRD) as well as the calcite crystals are homogenously connected with big crystals of quartz.

The Conservation Possess of the Mural Paintings: XRD analysis revealed that the ground layer is full of salts with high percentage because of The solubilized salts in the groundwater rising in walls, the daily sun light or the high artificial light dried out the paintings, so the salts crystalize and recrystallize, becoming bigger and so causing interior pressure leading to the detachments of paint layers [4], First of all stopping the rising of groundwater in walls by albumin strips (the water stopper).

Then close the windows in the palace especially in second floor
Finally Choosing a suitable way for light with led lamps which has no heat.

The conservation process briefly consisted of:

a. Cleaning using soft and hard brushes (Figure 6).

b. Chemical cleaning using acetone for the hard stains.

c. Consolidation using Beva371 with concentration. $3 \%$ [5].

d. Retouching the paint layer using the suitable colors.

The Suggested way to Protect the Mural Paintings at El Shinawy Palace: This palace is preparing to be museum so the paintings Mural paintings must be protected by covering them with flat glass this method used widely in tombs in Luxor and Aswan to prevent visitors from touching the painted layers the flat glass must be light weight glass, smooth, high resistance for breaking and scratches as well as high transparent, it should also cutout all the harmful radiations and with suitable thickness (Figure 7) [6,7].

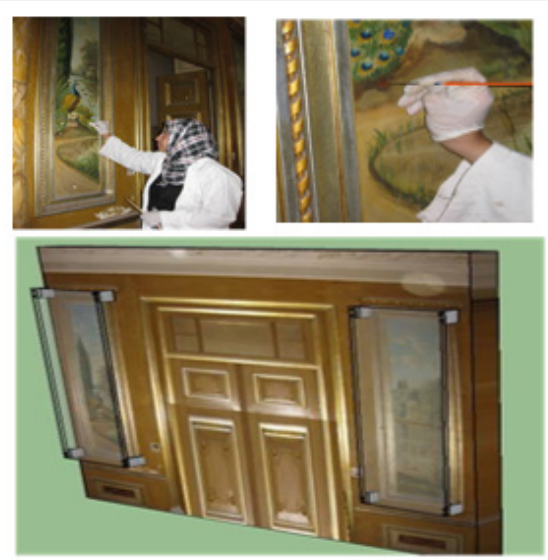

\section{Figure 7:}

a. The cleaning step.

b. The retouching step.

c. The final view of the special glass on mural paintings.

\section{Conclusion}

This paper is presenting the initial stages for restoration and conservation of mural paintings in El shinawy palace which full of all kind of arts , this study focused mainly on the deteriorated places of the mural paintings specially by identifying the percentage of the salts to assure its responsibility for the 
detachments of paint layers, the mural paintings in El Shinawy palace suffered from two major and vital deterioration factors from salts ,the high artificial light and the touch of visitors to the paintings which cause the greasy stains .

\section{References}

1. Hernandéz AR, Cançado AC (2017) Analisis de gestión socialbrasileña Stuart BH (2007) Analytical techniques in materials conservation. John Wiley \& Sons Ltd, England, UK, pp. 142 -144.

2. Arnold A, Zehnder KK (1987) Monitoring Wall Painting Affected by Soluble Salts. In: The Conservation of Wall Painting Proceedings of Symposium, Organized by Court auld Institute of Art \& Getty Conservation Institute, London, UK, pp. 103-115.
3. Ashurst J (1998) Conservation of building \& decorative stone, plant a tree, Butterworth, Great Britain, p. 15.

4. Mora P, Mora L (1984) Conservation of Wall Paintings, Butter Worths, Heinemann London, UK, pp. 1-494.

5. Amorso G, Fassina V (1983) Stone decay and atmospheric pollution?Cleaning, Consoldation \& Protection. New York, USA, pp. 115.

6. Middletion A, Uprichard A (2008) The Nebamun Wall Paintings. The British Museum, London, UK, p. 25.

7. Feissel A (1997) Microclimatic Condition, In the Wall Painting of the Tomb of Nefertari First Progress Repant. The Getty Conservation Institute, USA, p. 4.

\section{Your next submission with Juniper Publishers will reach you the below assets}

- Quality Editorial service

- Swift Peer Review

- Reprints availability

- E-prints Service

- Manuscript Podcast for convenient understanding

- Global attainment for your research

- Manuscript accessibility in different formats

( Pdf, E-pub, Full Text, Audio)

- Unceasing customer service

Track the below URL for one-step submission https://juniperpublishers.com/online-submission.php 